\title{
PENGABDIAN PADA MASYARAKAT TERPADU (PPMT) \\ BAGI LANSIA DUSUN KRAJAN, DESA MAJAKSINGI, KABUPATEN MAGELANG
}

\author{
Heni Setyowati Esti Rahayu, Puspita Septie Dianita, Desy Arifatul Hidhayah, \\ Ninda Cahyaningrum, Wahyu Indah Larasati, Muhammad Firdaus Dewa Kusuma \\ Fakultas Ilmu Kesehatan, Universitas Muhammadiyah Magelang \\ E-mail: henisetyowati@ummgl.ac.id
}

\begin{abstract}
Increased life expectancy impacts the emergence of degenerative diseases in the elderly. In Krajan, Majaksingi Village, Borobudur District there were 192 (56.6\%) elderly people, 68 people had hypertension, 31 people had diabetes mellitus, 30 people had high cholesterol, 34 people had high uric acid, and 29 people had rheumatism. The Integrated Community Service Program (PPMT) aims to increase the knowledge of the elderly posyandu cadres about elderly health issues and prevention efforts so that the elderly's health status is expected to improve. The method used is community empowerment with the Participatory Rural Appraisal model. The results of this activity are cadres understand about diseases in the elderly and their prevention and are skilled in carrying out acupressure, elderly gymnastics, foot gymnastics and brain gymnastics. The community also plays an active role when planting family medicinal plants to prevent diseases in the elderly such as ginger, kencur, cucumber, spinach, aloe vera, temu ireng, sleigh, dlingo, bengkle, and kapulogo. The community has been able to continue the activities taught at the time of PPMT, and even one person has been appointed who is responsible for continuing the activities. Conclusion: PPMT is very beneficial for improving the health of the elderly. Activity outputs are publications in mass media, posters, video activities and scientific articles.
\end{abstract}

Keywords: Lansia; Penyakit Degenerative; PPMT

\section{PENDAHULUAN}

Seiring meningkatnya derajat kesehatan dan kesejahteraan penduduk akan berpengaruh pada peningkatan Usia Harapan Hidup (UHH) di Indonesia. Berdasarkan laporan World Health Organization (WHO), pada Tahun 1980 UHH adalah 55,7 tahun, angka ini meningkat pada tahun 1990 menjadi 59,5 tahun dan pada tahun 2020 diperkirakan UHH menjadi 71,7 tahun. Meningkatnya populasi lansia ini membuat pemerintah perlu merumuskan kebijakan dan program yang ditujukan kepada kelompok penduduk lansia sehingga dapat berperan dalam pembangunan 


\section{GEMASSIKA: Jurnal Pengabdian Kepada Masyarakat}

Vol. 4 No. 1 Mei 2020

dan tidak menjadi beban bagi masyarakat. Undang-Undang No 13 Tahun 1998 tentang kesejahteraan lansia menetapkan, bahwa batasan umur lansia di Indonesia adalah 60 tahun ke atas. Undang-undang Nomor 36 Tahun 2009 pasal 138 ayat 1 menetapkan bahwa upaya pemeliharaan kesehatan bagi lanjut usia harus ditujukan untuk menjaga agar tetap hidup sehat dan produktif secara sosial maupun ekonomis sesuai dengan martabat kemanusiaan. Ayat 2 menetapkan bahwa Pemerintah wajib menjamin ketersediaan fasilitas pelayanan kesehatan dan memfasilitasi kelompok lanjut usia untuk dapat tetap hidup mandiri dan produktif secara sosial (Kementrian Kesehatan, 2013).

\section{MASALAH, TARGET DAN LUARAN}

Desa Majaksingi adalah salah satu desa wisata yang berada di Kecamatan Borobudur. Desa Majaksingi memiliki 12 dusun salah satunya adalah dusun Krajan. Di dusun Krajan terdapat 2 tempat wisata yaitu balkondes Majaksingi dan rumah kamera. Jumlah penduduk dusun Krajan adalah 339 orang dengan jumlah laki-laki 165 dan jumlah perempuannya 174. Berdasarkan hasil wawancara kepada kader ditemukan bahwa terdapat $192(56,6 \%)$ orang lansia. Seluruh lansia aktif mengunjungi kegiatan Posyandu.
Dari 192 lansia ditemukan 68 orang mengalami hipertensi, 31 orang mengalami diabetes melitus, 30 orang mengalami kolesterol tinggi, 34 orang mengalami asam urat tinggi, dan 29 orang mengalami rematik. Kondisi ini sesuai dengan konsep bahwa ketika terdapat banyak lansia atau mayoritas kelompok usia lansia maka penyakit degenerative akan muncul seperti hipertensi, stroke, diabetes melitus, dan artritis (Zaenurrohmah \& Rachmayanti, 2013). Apabila sakit, maka lansia berobat ke posyandu atau puskesmas Borobudur. Kebiasaan hidup lansia yaitu kurang olahraga, kurang mengontrol atau memilah makanan yang sehat dan penduduk kurang paham mengenai pemanfaatan tanaman keluarga untuk obat-obatan. Kebiasaan hidup atau perilaku yang tidak sehat ini yang sering menimbulkan banyak penyakit (Widodo, 2016).

Di dusun Krajan tersebut sudah terbentuk Posyandu Mawar 3 yang diadakan setiap satu bulan satu kali. Program kegiatan yang dilakukan yaitu pemeriksaan balita, ibu menyusui, dan lansia. Kader yang membantu jalannya posyandu berjumlah 4 orang. Kader Posyandu lansia digabungkan dengan kader kesehatan balita, sehingga sering mengalami keterbatasan dalam memberikan edukasi tentang kesehatan lansia maupun motivasi 
dalam menggerakkan pola hidup sehat. Di samping itu kader juga belum pernah mendapatkan pelatihan tentang kesehatan lansia dan pengelolaan posyandu lansia.

Berdasarkan beberapa permasalahan pada Posyandu di dusun Krajan dan masalah kesehatan lansia yang berada di dusun tersebut maka akan dilaksanakan Program PPMT (Pengabdian Pada Masyarakat Terpadu) untuk meningkatkan pengetahuan kader posyandu lansia tentang pengelolaan posyandu lansia dan masalah kesehatan lansia serta upaya pencegahannya sehingga diharapkan status kesehatan lansia meningkat. Luaran dari kegiatan ini adalah publikasi di media masa, poster, video kegiatan dan artikel ilmiah.

\section{METODE PELAKSANAAN}

Metode pelaksanaan kegiatan menggunakan Participatory Rural Appraisal (PRA) berupa sosialisasi, dan kemudian diberikan pelatihan, pemeriksaan kesehatan lansia dilanjutkan pendampingan. Tahapan pelaksanaan kegiatan meliputi kegiatan: 1) perencanaan (20-30 jam) terdiri dari kegiatan pendekatan dengan tokoh masyarakat, mengurus perijinan, melakukan survey lokasi untuk menggali masalah dan potensi yang ada kemudian dilanjutkan dengan penyusunan proposal, 2) pelaksanaan (60-70 jam) terdiri dari kegiatan pelatihan tentang masalah kesehatan lansia dan pencegahannya, pengelolaan posyandu lansia, tanaman obat keluarga (TOGA), pemeriksaan kesehatan dan senam lansia serta pendampingan, dan 3) pelaporan dan tindak lanjut (50-70 jam): terdiri dari penyusunan laporan kegiatan, penyusunan artikel ilmiah, publikasi pada media masa dan pembuatan video.

\section{HASIL PEMBAHASAN}

Adapun kegiatan PPMT secara keseluruhan akan diuraikan di bawah ini:

a. Sosialisasi kegiatan

Sosialisasi kegiatan PPMT dilaksanakan pada Hari Rabu 5 Februari 2020 di Balai Desa Majaksingi dan dihadiri oleh Ibu PLKB, Bapak Ibu Lurah, Ibu Bidan, Ibu PKK. Tim menyampaikan bahwa tema yang diambil dalam kegiatan PPMT ini bertujuan untuk meningkatkan derajat kesehatan lansia di Dusun Krajan, Kelurahan Majaksingi. Kegiatan yang akan dilakukan adalah sosialisasi masalah kesehatan lansia dan upaya pencegahannya, pemeriksaan kesehatan lansia dan senam lansia serta perintisan tanaman obat keluarga 
(TOGA) untuk dimanfaatkan sebagai pencxegahan masalah kesehatan lansia seperti hipertensi dan DM. Dari kepala desa menyambut baik kegiatan PPMT ini dan berharap kegiatan ini bisa benarbenar memberikan dampak positif pada kesehatan lansia dan dari pihak desa akan mendukung penuh agar kegiatan ini bisa berjalan dengan lancar.

b. Pelatihan

1) Pelatihan penanaman tanaman obat keluarga (toga) dan pemanfaatannya. Kegiatan penanaman toga bertujuan untuk meningkatkan ketersedian bahan-bahan obat yang bisa dimanfaatkan untuk mengatasi masalah kesehatan pada lansia seperti menanam jahe, kencur, kunyit, daun sereh dan lain-lain. Kegiatan sudah dilaksanakan pada tanggal 5 Februari 2020 bertempat di Balai Desa, Dusun Krajan, Desa Majaksingi, Kecamatan Borobudur. Kegiatan ini dihadiri oleh Ibu PLKB, Bapak Ibu Lurah, Ibu Bidan, Ibu PKK dan sejumlah masyarakat sehingga seluruh peserta yang hadir adalah 54 orang. Acara dilaksanakan bersamaan dengan kegiatan Pertemuan PKK, Desa Majaksingi. Perangkat desa dan masyarakat sangat menyambut baik dengan program kegiatan ini dan berharap agar tanaman obat keluarga segera dilaksanakan sehingga kelak dapat digunakan untuk mengobati penyakit yang banyak diderita oleh lansia di Dusun Krajan, adapau tanaman yang ditanam adalah jahe, kencur, mentimun, bayam, lidah buaya, temu ireng, tanaman gigring, dlingo, bengkle, dan kapulogo.

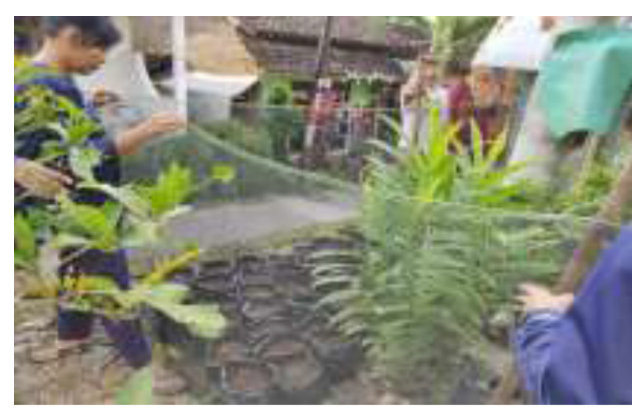

2) Pelatihan kader posyandu lansia.

Kader posyandu lansia membutuhkan pelatihan pengelolaan posyandu lansia agar bisa melaksanakan kegiatan posyandu dengan benar sehingga bisa meningkatkan derajat kesehatan lansia melalui edukasi dan pemeriksaan kesehatan secara rutin. Pelatihan kader lansia dilaksanakan pada hari Minggu, 1 Maret 2020 dan hari Sabtu, 7 Maret 2020, bertempat di rumah warga (Krajan, Majaksingi, Borobudur). Materi 
dalam pelatihan ini tentang penyakitpenyakit degeneratif(DM, hipertensi, Demensia dll) pada lansia beserta upaya penanganannya. Kegiatan berjalan dengan lancar dan kader sangat antusias mengikuti pelatihan ini apalagi ketika mempraktekkan akupresur untuk menurunkan tekanan darah, senam kaki untuk pasien DM. Di samping itu untuk mencegah demensia pada lansia juga diajarkan senam otak.

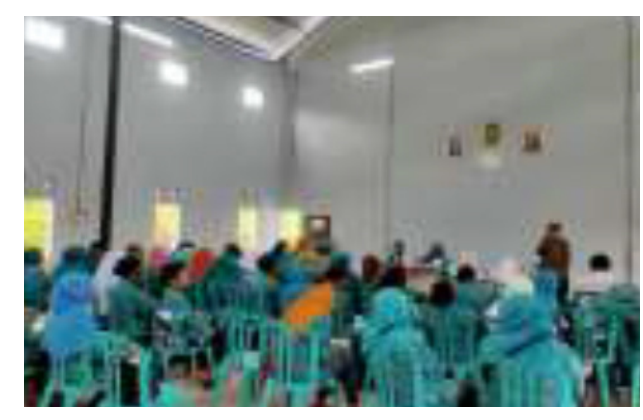

3) Pemeriksaan kesehatan dan Senam lansia

Pemeriksaan kesehatan berupa pengukuran tekanan darah, timbang berat badan, pemeriksaan kadar gula dalam darah sebagai deteksi dini faktor resiko munculnya gangguan. Kegiatan ini dilaksanakan pada tanggal 7 Maret 2020, bertempat di rumah warga (Krajan, Majaksingi, Borobudur), Hasil dari kegiatan pemeriksaan tersebut adalah ma- yoritas warga khususnya pra lansia mengalami hipertensi dan kami memberi solusi setiap permasalahan menggunakan tanaman obat keluarga.

4) Pelatihan tentang masalah kesehatan pada lansia beserta pencegahannya.

Kegiatan ini telah dilasanakan pada tanggal 21 Maret 2020 diikuti oleh 25 orang. Materi yang disampaikan tentang masalah kesehatan lansia yaitu hipertensi dan DM beserta upaya pengendaliannya. Pelatihan ini bertujuan untuk mengenalkan kepada para lansia tentang masalah kesehatan yang terjadi dan upaya pencegahannya sehingga diharapakan para lansia akan melakukan upaya peningkatan kesehatan dan pencegahan munculnya penyakit. Kegiatan ini dihadiri oleh 25 orang yang terdiri dari Ibu kepala Desa, Ibu Carik, Ibu Kader, Ibu kepala Dusun, dan masyarakat. Kegiatan ini dapat berjalan dengan baik terbukti dengan banyaknya pertanyaan masyarakat yang diajukan dan sebagain besar masyarakat sudah bisa melaksanakan akupresur untuk hipertensi, DM kemudian senan kaki untuk DM dan senam otak. 


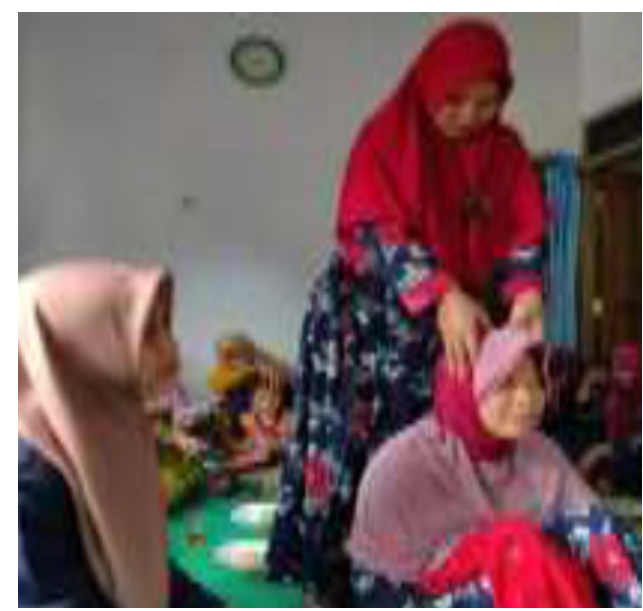

5) Sosialisasi pencegahan penularan virus corona

Kegiatan ini dilasanakan meskipun tidak ada dalam proposal karena wabah pandemi covid-19 yang semakin merajalela dan membahayakan. Kegiatan ini dilaksanakan setelah kegiatan posyandu bulanan selesai yaitu hari Kamis, 16 Maret 2020. Bertempat di kediaman bu carik dan dihadiri oleh 44 orang. Hadir dalam sosialisasi tersebut Ibu kepala Desa, Ibu Carik, Ibu Kader, Ibu kepala Dusun, Bidan dan masyarakat. Materi disampaiakn oleh Dr. Heni Setyowati ER, SKp, MKes sebagai ketua pelaksana PPMT. Peserta sangat antusias mengikuti terbukti banyaknya pertanyaan yang diajukan dan pada saat praktek cuci tangan yang benar, peserta akhirnya bisa memahami cuci tangan yang dilakukan belum betul bahkan belum terbiasa cuci tangan.

c. Pendampingan

Pendampingan dilakukan untuk menjamin keberlanjutan program yang sudah diajarkan kepada masyarakat bisa terlaksana sesuai dengan yang sudah diajarkan sehingga pada saat kegiatan pengabdian oleh tim selesai, masyarakat bisa mandiri melaksanakannya. Pendampingan dilaksanakan selama tiga minggu. Dari hasil evaluasi yang dilaksanakan oleh tim, masyarakat sudah bisa melanjutkan kegiatan-kegiatan yang diajarkan pada saat PPMT. Bahkan telah ditunjuk satu orang personal yang bertanggung jawab untuk melanjutkan kegiatan.

\section{KESIMPULAN DAN SARAN}

PPMT bagi dusun Krajan sangat bermanfaat untuk meningkatkan pemahaman kader dan lansia tentang penyakit pada lansia dan upaya pencegahannya sehingga diharapkan lansia aktif melaksanakan upaya pencegahan dengan melaksanakan pemeriksaan secara rutin, melaksanakan akupresur untuk mencegah hipertensi, senam lansia, sehingga kesehatan lansia akan semakin meningkat. 


\section{DAFTAR PUSTAKA}

Aldo, R. R., \& Gustin, R. K. (2019). Jurnal Kesehatan. Jurnal Kesehatan, 2, 106-111.

Handajani, A., Roosihermiatie, B., \& Maryani, H. (2010). Faktor-faktor yang berhubungan dengan pola kematian pada penyakit degeneratif di indonesia. Buletin Penelitian Sistem Kesehatan, 13, 42-53.

Kementrian Kesehatan, R. I. (2013). Gambaran Kesehatan Lanjut Usia di Indonesia.

Stefanus Mendes Kiik, Junaiti Sahar, H. P. (2018). Peningkatan Kualitas Hidup Lanjut Usia (Lansia) di Kota Depok Dengan Latihan Keseimbangan. Jurnal Keperawatan Indonesia, 21(2), 109-116. https://doi.org/10.7454/jki.v21i2.584

Widodo, S. (2016). PEMBERDAYAAN KEMAMPUAN LANSIA DALAM DETEKSI DINI PENYAKIT DEGENERATIF Widodo, Sumardino. Jurnal Terpadu Ilmu Kesehatan, 5(2), $110-237$.

Zaenurrohmah, D. H., \& Rachmayanti, R. D. (2013). Hubungan pengetahuan dan riwayat hipertensi dengan tindakan pengendalian tekanan darah pada lansia. Jurnal Berkala Epidemiologi, 5(J2), 174-184. https://doi.org/10.20473/jbe.v5i2.2017.174-184 